\title{
Houses built on sand
}

The crisis consists in the fact that the old [order] is dying and the new cannot be born; in this interregnum a large variety of morbid symptoms appear.

Antonio Gramsci, Passato e presente

Ana wa akhi ala ibn ammi, ana wa ibn ammi ala algharib.

[My brother and I against our cousin, my cousin and I against a stranger.]

An old Beouin saying

In the fallout from the Arab Uprisings, a number of parallels have been drawn with the Thirty Years' War across Europe in the seventeenth century. ${ }^{1}$ Take the opening lines of an article by Richard Haas, President of the Council on Foreign Relations:

It is a region wracked by religious struggle between competing traditions of the faith. But the conflict is also between militants and moderates, fueled by neighboring rulers seeking to defend their interests and increase their influence. Conflicts take place within and between states; civil wars and proxy wars become impossible to distinguish. Governments often forfeit control to smaller groups - militias and the like - operating within and across borders. The loss of life is devastating, and millions are rendered homeless. That could be a description of today's Middle East. In fact, it describes Europe in the first half of the seventeenth century. ${ }^{2}$

Although the parallels are obvious, this argument reveals a great deal about analysis of the region, drawing upon Eurocentric approaches and linear trajectories of development. Moreover, as Lorenzo Kamel suggests, this is part of a broader project of 'medievalising' the region, reducing identities to sectarian schisms that have their roots in what Barack Obama referred to as 'ancient hatreds' that have defined the history of 
Islam. ${ }^{3}$ This approach is part of a broader Orientalist strategy to 'other' the Middle East and neglects the multifarious factors that underpin the emergence of different types of involvement and relationships that are shaping the region.

Others have sought to categorise recent events as efforts to bring congruence to nation and state amid the alleged imposition of Western conceptions of statehood. ${ }^{4}$ Efforts to exert power and regulate life amid the presence of powerful movements has had a devastating impact on regional politics. The spread of ideas and ideologies across state borders routinely opened up schisms between regimes and societies and, in turn, shaped the spatial landscape. Amid the presence of a shared normative environment populated by a melange of identities and ideologies within and across state borders, what happens in one state has the capacity to impact upon political life in another. Thus, regime efforts to maintain domestic power are predicated upon regional machinations, which may also impact upon domestic politics.

Central to such fusion is a concern with creating order and regulating space. Agamben's global nomos, the spatialised localisation of the unlocalisable exception shapes international politics. Conditioned by neo-liberal modernity, the emergence of political projects fall in line with such visions. Yet as we have seen, conditions that facilitate ordnung and ortung have become increasingly contested, creating new spaces that challenge the organisation and ordering of space. State-building projects created zones of indistinction, which are simultaneously spaces of restriction and spaces of possibility to be moulded in accordance with local context and contingency. With the complex relationship between ordnung and ortung, new possibilities emerge for the reorganisation of political life.

Zones of indistinction and possibility emerge in numerous forms, perhaps most obviously as a consequence of competing theological and political interpretations of sovereign power. In discussions with people across the region about the nature of statehood, prominent themes included legitimacy deficits and the erosion of the sovereign state. ${ }^{5}$ Amid the presence of a wide range of groups exerting power and influence within and across territorial borders, legitimate claims to sovereign control and authority become increasingly complex. In a number of cases, two or more groups exert regulatory power over people in particular territorial areas, not necessarily spatially bounded, leading to competition domestically and regionally. ${ }^{6}$

With the onset of the uprisings, new arenas of competition emerged which brought together local and regional actors, simultaneously serving as zones of possibility and restriction as international players sought to manipulate domestic affairs often for their own ends. ${ }^{7}$ Yet the increasingly securitised and politicised role of religion, particularly within the context of the rivalry between Saudi Arabia and Iran has left regimes open to criticism while state security is undermined by the ability of clerics in one state to speak to audiences in another. When domestic audiences are framed as a security threat, it is hardly surprising that some communities are perceived to have sought guidance and support from co-ethnic or sectarian kin. ${ }^{8}$ Evoking memories of Paul Noble's regional echo chamber, this chapter shows how the fallout 
from the Arab Uprisings has consequences for the organisation of the contemporary Middle East.

\section{Echo chambers and zones of possibility}

Most scholars typically agree that the arrangement of Middle Eastern politics and security is fundamentally different to the 2003 landscape, where new ways of ordering space have emerged, appearing to take on sectarian characteristics and underpinned by anti-Iranian sentiment. Yet it is easy to misrepresent such change. As the late Fred Halliday noted, 'There are two predictable, and nearly always mistaken, responses to any great international upheaval: one is to say that everything has changed; the other is to say that nothing has changed.' ${ }^{9}$ The answer, of course, is somewhere in-between, albeit contingent on time, place and space.

The toppling of Saddam Hussein created a 'new' space of competition between Saudi Arabia and Iran, which escalated after the uprisings of $2011 .{ }^{10}$ As we saw earlier, Morten Valbjørn and André Bank argue that it is generally accepted that the region is 'qualitatively different from earlier days', yet in spite of this difference, they argue that the Middle East is still shaped by a form of Arab nationalism and shared ethnic experiences. ${ }^{11}$ Jerrold Green's comments in a 1986 article that 'Arab politics is still Arab'12 remains true, documenting that although nationalist concerns remain, they are located within geopolitical machinations and the framing of a 'Persian other' alongside sectarianisation to argue that recent events are still shaped by nationalist concerns. This view has clear resonance in 'high politics', but has also found traction within states, particularly those who are sites of direct competition between the Saudis and the Iranians. With this in mind, Paul Noble's comments about the Middle Eastern echo chamber as 'a set of interconnected organisms separated only by porous membranes, or, alternatively a large-scale domestic system divided into compartments of varying degrees of permeability' remain relevant. ${ }^{13}$

Central to the organisation of regional politics is the ability of religion to shape the conflation and calibration of space and politics, driven both by local and regional contexts. ${ }^{14}$ While the 2003 war in Iraq facilitated the emergence of violence along sect-based lines - driven by the vociferously anti-Shi'a rhetoric of Abu Musab Al Zarqawi, the leader of Al Qa'ida in Iraq - the 2006 Hizballah war with Israel brought sectarian politics into regional calculations. Breaking norms in the 'Arab game of politics', Saudi Arabia, Jordan and Egypt publically rebuked Hizballah's decision to go to war, demonstrating concern at the popularity of Hassan Nasrallah and the group more broadly. ${ }^{15}$ In spite of these concerns, in the aftermath of war the kingdom used its financial reserves to help rebuild Dahiyeh, in spite of sectarian difference, perhaps suggesting that the kingdom was held hostage by the remnants of Arab nationalist norms and its enmity towards Israel. Twelve years later, it is hard to envisage such behaviour from the Al Saud. 
The fallout from the Arab Uprisings once again demonstrated the collapse of the distinction between internal and external as actors from across the region became embroiled in the domestic affairs of other states. Of course, this is hardly a new phenomenon, as we saw with Arab nationalism, but in recent years this has taken on increasing sect-based dimensions. As a consequence, when political crises emerge, they are also located within broader regional dynamics. Events in Syria offer a good example of this, transforming, as Bassell Saloukh suggests, from a Leviathan to a weak state, penetrated by regional actors as a consequence of the interplay between domestic and regional forces. ${ }^{16}$ In spite of this weakness, the Assad regime has exercised brutal force over its population, using all manner of strategies to regulate life and to subjugate life to death.

As the war escalated, it took on regional and international importance as a zone of indistinction, caught in competition between Iran and Saudi Arabia, and Russia and the United States. A range of networks were mobilised to shape the conflict, along sectarian, ethnic, tribal and familial lines, creating a situation that was far more complex than the reductive analysis of 'ancient hatreds' or 'proxy wars' suggest. The collapsing distinction of internal and external is not limited to Syria as events in Lebanon, Bahrain, Yemen and Iraq reveal. Although this distinction is predominantly a consequence of security calculations, economic factors remain important both independently and as a part of security calculations concerns, amid the provision of support for communal groups across state borders. ${ }^{17}$ Fundamentally, it is about regimes wanting to create order and stability.

While sovereignty and respect for the sanctity of territorial borders is routinely used as a mechanism to both justify and criticise political action across the region, the extent to which the norm of sovereignty is sacrosanct is contingent upon context. ${ }^{18}$ For many, external interference in the domestic affairs was seen as a 'tool of repression ${ }^{19}$ as networks were mobilised across state borders. Yet in order to mobilise these networks, political and socio-economic conditions must facilitate interactions between local and global. Here, we see how contingent factors shape different contexts, even within shared normative environments. For instance, although a growing number of young people advocate the separation of religion and politics, ${ }^{20}$ the power of religion within informal power structures is undeniable, shaping social, economic and political landscapes, with repercussions for spatial ordering. ${ }^{21}$

As a consequence, the need to contextualise events is paramount, requiring the location of events within local and regional environments and the identification of contingent factors that shape action. Of course, such contexts are underpinned by broader economic trends, as a consequence of globalisation and neoliberal agendas that collapse the distinction between internal and external. ${ }^{22}$ Such neoliberal forces also play an important role in shaping the political landscape, both economically and socially. Widespread investment in Lebanon has fed into increasingly visible economic divides across urban environments, which in turn have political and social consequences. ${ }^{23}$ Such economic divides have political and social dimensions resulting in the reproduction of sectarian identities alongside the emergence of powerful mafias such as the Shahiba in Syria who capitalise on local contexts for their own ends. ${ }^{24}$ 
Amid the melange of identities across the Middle East, how a regime behaves towards one group will have repercussions with regard to how such a group behaves in response. The spread of identities creates space for - and the perception of - external involvement and manipulation of particular causes; local grievances and agendas quickly become imbued with regional meaning. In Syria, Sunni groups are said to frame themselves as Salafi in an attempt to secure money from Saudi Arabia, as members often changed their names to something more 'appropriate' to derive money from the kingdom. ${ }^{25}$

Reform in one state is also seen to have implications for groups in another. In Bahrain, a Saudi-imposed red line is alleged to have prevented the emergence of a democratically elected second chamber to thwart the proliferation of democratic aspirations into the eastern province of Saudi Arabia. ${ }^{26}$ This same red line also resulted in the removal of the Crown Prince from the public eye after an ill-fated effort to facilitate dialogue between opposition groups and the ruling family. ${ }^{27}$

The conflation of internal and external agendas also shaped the character of institutional structures, as fragmenting sovereignty left institutions open to the influence of regional actors. In Iraq, for instance, the police were perceived by some to be 'controlled not by the Ministry of the Interior (MOI) but by the Islamic Supreme Council of Iraq (ISCI)/Badr, particularly in Karbala, Diwaniyah and Nasiriyah.. ${ }^{28}$ Moreover, the evisceration of state infrastructure in post-2003 Iraq left many Sunnis unemployed amid social and political chaos, and increasing the target of Shi'a militias. ${ }^{29}$ In early 2017, PMUs such as Badr were integrated into formal state structures with the establishment of a parallel military force, much to the chagrin of Sunni communities whose experiences of marginalisation and violence at the hands of the PMUs appear to have been ignored. ${ }^{30}$

\section{Sectarianisation as geopolitics by other means}

On 2 January 2016, Saudi Arabia executed the Shia cleric Nimr Al Nimr for his involvement in protests in the eastern province. Sheikh Nimr had long been an advocate of political reform in Saudi Arabia, a staunch critic of authoritarian rule and a prominent figure in the uprisings in 2011. In response, protests broke out across the eastern province, in Kashmir, Pakistan, and protesters stormed the Saudi consulate in Tehran as Nimr's execution was met with global condemnation. ${ }^{31} \mathrm{~A}$ few months earlier, in a much less covered event, Kuwaiti officials arrested a number of nationals amid suggestions that they had been planning an attack against the state; ${ }^{32}$ it was alleged that the group was supported by Iran. Of course, most forms of domestic unrest across the region, particularly after the uprisings, have been framed as a consequence of nefarious Iranian behaviour.

Following the fragmentation of sovereign structures, power has shifted away from a number of regimes, providing scope for the emergence of powerful war machines in the guise of militias, mafias and gangs, often underpinned by sectarian identities. ${ }^{33}$ 
This transformation has provided opportunities for actors to seek to shape the region in accordance with their own image, with repercussions for domestic politics in the process. Thus, geopolitical ambitions have seen actors mobilising and harnessing the power of religious identities and groups along sectarian lines across the region in what has become known as the sectarianisation of politics. ${ }^{34}$

This type of strategy served to support narratives of Iranian manipulation and interference. Narratives supporting sectarianisation have had a serious impact on people across the region, not only in terms of their political performances but also concerning their own identities within the context of an evolving and increasingly precarious environment. There are regional and domestic repercussions of the sectarianisation of political life. As political contexts become imbued with sectarian tensions, the ordering of space takes on a geopolitically charged meaning, with Saudi Arabia at the vanguard of efforts to counter the Iranian threat. Efforts to challenge this ordering creates a precarious environment, as we shall see below.

In a changing geopolitical environment, narratives espousing the construction of a Shi'a crescent and cultivating fears of the Persian other became more prominent, as regimes sought to frame domestic events as a consequence of regional machinations. For a large number of Sunni Arabs across the Gulf, Iranian activity is the source of instability across the Middle East, resulting in the increasing politicisation and securitisation of the region. ${ }^{35}$ Regime responses to protest movements were framed as necessary retorts to perfidious action from fifth columnists supported by Tehran. Conflicts emerging from the fragmentation or weakness of state structures took on new meaning as they became shaped by geopolitical agendas. Local groups became embroiled in regional dynamics and vice versa, albeit the capacity of regional actors to affect change locally was determined by both power and perceptions of legitimacy. ${ }^{36} \mathrm{In}$ the early stages of protests, events in Bahrain and Yemen were largely free of sectarian traits, but as external actors became more prominent, local context was given new meaning by incoming actors. In some cases there were suggestions that local groups took advantage of such events, moulding their identities according to the perceived wishes of external actors in search of funding, although this suggests a rather transient and instrumentalised view of identity. ${ }^{37}$

A wide range of tactics have been used to achieve sectarianisation, shaped by context-specific contingent factors. Although the prominence of religion provides scope for politicians to use religious and sectarian discourses for their own ends, this is seen to offer a means to 'to mobilise and manipulate their people', and we must locate broader narratives within local contexts. ${ }^{38}$ Yet as Haid Haid stresses, we must distinguish between the motives of local and regional actors, which may coalesce at times but may not have the same objectives. ${ }^{39}$ By doing this, we are better placed to see how geopolitical aims have been achieved through recourse to sectarian membership. This distinction also helps us consider how sectarian identities have been manipulated by sectarian entrepreneurs, those who are able to manipulate sectarian boundaries and who 'profit from these boundaries become the defining markers of a particular segment of society. ${ }^{40}$ While sectarian entrepreneurs play a prominent role in shaping socio-political climates, they are conditioned by the interaction of local context and 
contingency, and the rhythms of regional forces, facilitating the sectarianisation of political life.

The sectarianisation of political life has serious implications for the regulation of life more broadly, for both states and their peoples. One journalist suggested that viewing events through a sectarian prism is how people have had to define themselves in order to survive. Essentially, 'it is a way of saying I am less likely to be killed by this person than if I align with that person. ${ }^{41}$ While such analysis may appear reductive, the conflation of politics, economics and sect has loaded sect-based identities with existential importance, to the extent that the interaction of each facet shapes the other. In places such as Lebanon, sectarian dimensions risk becoming all encompassing, providing business elites - both legitimate and mafias - with the mechanisms to increase their profit margins and political elites with mechanisms of control. Quickly this became an existential issue, not because of sectarian difference itself, but because of the political and economic manifestations of this difference and the ways in which this plays out across all aspects of life. ${ }^{42}$

One possible response to such issues is to move to a federal model, such as in Lebanon, or to formalise the quasi-federalism in operation across Iraq, yet this too is problematic. ${ }^{43}$ While the current Prime Minister Haider Al Abadi recognises decentralisation as a mechanism to empower local communities within the context of a nationalist project, his predecessor Nouri Al Maliki viewed decentralisation as a 'hidden plot' and part of an agenda to divide the country. Others suggest that opening Iraq - and indeed Syria will 'open Pandora's box', resulting in 'a race to the bottom in each individual canton [over] who is more Sunni, who is more Shia who is more Kurdish. ${ }^{44}$ Supporting this perception, Haider Al Khoei argued that unlike a century ago, if Iraq were to be partitioned, 'it is not going to be white men in suits meeting in London and Paris drawing lines on a piece of paper and imposing them; it is going to be young, angry armed men on the ground who will impose, change or redraw those lines with their blood'. ${ }^{45}$ Acknowledging the concern about increasing instability and Iranian influence in Iraq, Saudi Arabia has attempted to build alliances with a number of Shi'a parties who are seen as 'nationalist', including with Moqtada Al Sadr. ${ }^{46}$

Much like in Iraq, the fragmentation of Syria drew in regional and international actors working towards their own geopolitical goals. ${ }^{47}$ The provision of support to a range of different sides in a multi-faceted conflict served to entrench divisions that quickly took on sectarian dimensions through a policy of sect-coding by the Assad regime, creating an intractability that prevents the swift resolution of the conflict. In contrast to events in Bahrain and Yemen, where Saudi efforts sought to preserve the status quo, in Syria - much like Iraq - Riyadh attempted to topple the Assad regime to reduce Iranian influence across the Levant. As Madawi Al Rasheed notes, Saudi policy in Syria can be described as an attempt to 'win Syria back to the Arab fold', in doing so, dramatically reducing Iranian influence across the region. Yet the internationalisation of the conflict geographically and through the spread of Wahhabism helped to secure the survival of the Assad regime while also making the conflict increasingly intractable.

In Egypt, the election of Mohammad Morsi as President posed a different kind of challenge to Saudi Arabia and the UAE. The ikhwan has long challenged Saudi Arabia's Wahhabi vision of Islam, in spite of members of the group being brought into 
the state apparatus during the 1960s. The Morsi government, the first democratically elected Islamist President, offered an alternative vision of the ordering of political life to that propagated by the Al Saud, while their social activity was seen as a threat in the UAE. At this time, Qatar offered public support to the Morsi government, causing a great deal of irritation to their Gulf neighbours. Fuelling the concerns of many, Morsi's government appeared willing to improve relations with Iran, much to the chagrin of Saudi Arabia. As a consequence, it was hardly surprising that the toppling of the Brotherhood was well received and shortly after the coup, Saud Arabia, the UAE and Kuwait pledged $\$ 12$ billion in aid to Abdul Fatah Al Sisi's 'new', ancien régime.

Bahrain has largely managed to control unrest, albeit at a price. In seeking to address demographic imbalances, naturalisation processes gave Bahraini passports to Sunnis from the Asian subcontinent and Africa, while members of the Shi'a community were framed as fifth columnists doing the bidding of Tehran. The societal implications of such a reframing may not be seen in the very near future, but schisms between different societal groups will emerge. In Lebanon, the influx of Syrian refugees has led to increasing xenophobia and the amorphous alignment of a number of indigenous Lebanese parties against the refugees. ${ }^{48}$ Similar forms of anti-refugee xenophobia are also found in Turkey as a consequence of the political, social and economic pressures placed on the state in order to accommodate those displaced from Syria. ${ }^{49}$

Fundamentally, such moves have positioned Arab and Sunni concerns front and centre within regional security calculations. Although a number of rulers have sought to cultivate new nationalisms, these are all too often predicated upon an exclusive view of national identity based upon shared communal characteristics of ethnicity and sect, defined against the other, cultivating racisms, fear and hatred in the process. Within this strategy, networks are mobilised and while traditionally along sect-based lines, it begins to take the form of regional patronage as richer states distribute financial resources in pursuit of their own ends.

\section{Geopolitical realignment}

Given the region's geopolitical importance it was hardly surprising that events took on an international dimension, becoming imbued with additional complexity and contradiction in the process. The most obvious example of this is in Syria, where fighting between regime and opposition figures was complicated by the presence of external actors providing support to a range of groups. While the United States, Saudi Arabia, Qatar and Turkey provided support to rebel groups, Russia, Iran and Hizballah supported the regime, ${ }^{50}$ yet it would be remiss to suggest that Tehran and Moscow agree on longer-term goals. ${ }^{51}$

Debate about how best to respond to the uprisings was shaped not only by events in the region but also by the domestic contexts of international states. The administration of US President Donald Trump was dominated by anti-Iranian sentiment, reflecting a 
marked shift from his predecessor Barack Obama, whose administration had taken a more conciliatory position towards Tehran. ${ }^{52}$ In a wide-ranging interview with Jeffrey Goldberg published in The Atlantic, Obama's views on the Middle East were articulated:

The competition between the Saudis and the Iranians - which has helped to feed proxy wars and chaos in Syria and Iraq and Yemen - requires us to say to our friends as well as to the Iranians that they need to find an effective way to share the neighborhood and institute some sort of cold peace. ${ }^{53}$

It was hardly surprising that Obama's words were not received well in Riyadh:

The Kingdom's 80 years of constant friendship with America to an Iranian leadership that continues to describe America as the biggest enemy, that continues to arm, fund and support sectarian militias in the Arab and Muslim world, that continues to harbor and host Al-Qaeda leaders, that continues to prevent the election of a Lebanese president through Hezbollah, which is identified by your government as a terrorist organization, that continues to kill the Syrian Arab people in league with Bashar Assad? ${ }^{54}$

Saudi Arabia's perception of Iranian foreign policy was made explicit through a number of newspaper opinion pieces. In one, Adel Al Jubeir argued that Iran sought to 'obscure its dangerous sectarian and expansionist policies, as well as its support for terrorism, by leveling unsubstantiated charges against the Kingdom of Saudi Arabia. ${ }^{55}$ Al Jubeir also stressed that Iran is 'the single-most-belligerent-actor in the region, and its actions display both a commitment to regional hegemony and a deeply held view that conciliatory gestures signal weakness either on Iran's part or on the part of its adversaries.' ${ }^{56}$

Such comments reveal a great deal about the alliance between Riyadh and Washington during the Obama administration. Once a mutually beneficial relationship driven by the strength of the personalities involved, cooperation between the two had become increasingly frayed. The extent of such fears prompted consecutive Saudi figures to frame Iran as an existential threat to Western audiences, including through the funding of a number of universities and think tanks across Washington, DC. ${ }^{57}$ Although ultimately unsuccessful in persuading the United States to strike against Iranian targets, Saudi securitisation moves fed into a regional realignment.

As a consequence of existential fears about the Iranian nuclear crisis and the ensuing framing of protest movements along sectarian lines, the balance of power across the region shifted. Decades-old suspicion and enmity between Sunni Arab states and Israel began to thaw at a state level - although data suggests that this is far less popular with domestic populations ${ }^{58}$ - as anti-Iranian sentiment brought long-time rivals together in a classic example of realpolitik.

Post 2011, changes in the organisation of regional security provided scope for a number of peripheral regional actors to take a more prominent role in regional affairs. A more pro-active Turkish foreign policy was matched by Qatar, seeking to 
establish itself as a regional force. While Israel continued to play a peripheral role in the region, happy to maintain the status quo and wary of instability brought by the uprisings, changing currents across the Middle East supported growing moves towards rapprochement with Saudi Arabia and other Gulf powers amid shared security concerns. ${ }^{59}$ While such moves gained momentum after 2011, diplomatic cables recall observations from King Hamad of Bahrain calling for 'real peace' with Israel so that 'we can all face Iran.' ${ }^{60}$

Amid such fears, it was hardly surprising that the Joint Comprehensive Plan of Action (JCPOA) agreed by the P $5+1$ and Iran was viewed with a great deal of consternation by many, who saw it as an agreement that would empower Tehran and its allies across the region. Fearing that Iran might develop a 'breakout capacity' while also leading to and an emboldened Hizballah, many in Israel, the Gulf and the United States were critical of the deal, ${ }^{61}$ leading to a range of securitisation efforts designed to suspend the 'normal politics' of diplomatic efforts and calling for a military strike against the Islamic Republic. ${ }^{62}$ Such calls reflect the growing uncertainty across the Middle Eastern security environment while also stressing the extent to which regional events possess international importance.

The election of Donald Trump as President of the United States in 2016 had a dramatic impact on the Middle East. On Trump's first official foreign trip as President, he visited Saudi Arabia and Israel to set out a bolder foreign policy, where his antiIranian message was well received in both states. The legacy of anti-Iranian sentiment from the Iraq War featured prominently in Trump's cabinet, with Mike Pompeo and John Bolton - two vehemently anti-Iranian hawks - holding prominent portfolios along with setting the scene for future policy trajectories. The anti-Iranian sentiment fed into the Trump administration's policy decisions, choosing to swiftly withdraw from the JCPOA, much to the concern of many across the world.

Although the rivalry between Riyadh and Tehran has come to occupy a central role in regional machinations, there are added complexities at play. A by-product of the policy of geopolitics by other means is the recent tension between Saudi Arabia and the UAE and Bahrain - and Qatar. Tensions between the two have historical roots but became increasingly fractious amid debates over who was responsible for coordinating support to rebel groups in Syria. Tensions rapidly escalated, prompting the withdrawal of Saudi, Bahraini and Emirati ambassadors from Doha, along with a threat to close Qatar's only land border and putting out tenders to turn the border into a canal. Although these tensions were defused, ambassadors were withdrawn again in June 2017 amid continued support for a number of Islamist groups such as the Muslim Brotherhood and Hamas - alongside perceived rapprochement with Iran that underpinned the decision. ${ }^{63}$ As a consequence, air and sea borders were closed and Qatari citizens were given fourteen days to return home.

A thirteen-point list of demands was given to Qatar and met with great scorn in Doha, where it was viewed as an attack on Qatari sovereignty. In conversation with a US TV show, Emir Tamim stated that, 'Our sovereignty is a red line. We don't accept anybody interfering with our sovereignty'. He later suggested that the blockade was a 
consequence of Doha's engagement with the Arab Uprisings, where a serious difference was exposed wherein Qatar 'stood by the people. They stood by the regimes.6 ${ }^{64}$

The blockade was a consequence of Doha's support for actors across the region deemed unpalatable to the Saudi bloc, including links with Iran, the Muslim Brotherhood and subversive activity in Bahrain. The leader of Bahrain's Al Wefaq, Ali Salman, was framed as a Qatari agent on the basis of a phone call between Salman and the Qatari Foreign Minister. ${ }^{65}$ Qatar has long played host to Islamist groups such as Hamas, the Taliban and the Muslim Brotherhood in an attempt to wield political influence across the Middle East. It has also provided support to groups across the region, both formally through foreign policy channels and informally, through $\mathrm{Al}$ Jazeera, much to the chagrin of Saudi Arabia. Amid existential concerns about regime survival, Islamist groups are seen to be a serious threat to regimes in Riyadh and Abu Dhabi. ${ }^{66}$ Yet in spite of this, a number of GCC states have empowered Salifist groups and the Muslim Brotherhood in an attempt to counter the threat from Shi'a groups. ${ }^{67}$

In response to Saudi actions, images of Emir Tamim drawn by the Qatari artist Ahmen bin Majed Amaaheed sprung up across Doha. The image, captioned 'glorious Tamim', appeared on skyscrapers, cars and T-shirts and the cult of personality was almost tangible. Although the blockade was seen to disrupt life across Qatar, preventing the development of the state amid the development of national infrastructure of the 2022 World Cup, the ability to import cows from the United States, ${ }^{68}$ olive trees from Italy, support from allies and the development of a 'blockade busting port ${ }^{369}$ meant that the impact of the Saudi-led actions was mitigated. Speaking to a hotel manager in September 2017, I asked about the impact of the blockade, to which the manager replied, 'Is that still happening?' The financial might of Qatar has left it with the capacity to circumvent external challenges, along with the repressive technologies to quell potential domestic unrest.

Yet as it fragments, the Gulf continues to be a region of international importance, not only because of the location of natural resources but also as a consequence of widespread diversification and integration into global supply chains. ${ }^{70}$ Increased foreign direct investment followed, while the region's prestige has been augmented by links with global sporting brands such as Arsenal, Barcelona and Manchester City, not to mention Qatar hosting the World Cup in 2022. Although demand for Gulf oil from the West has decreased following the establishment of fracking programmes in the United States, Russian and Chinese demand increases. ${ }^{71}$

Gulf leaders face a number of important challenges in balancing domestic agendas with regional relations, along with international obligations and increasing domestic discontent. ${ }^{72}$ Writing in 2011, Kristian Coates Ulrichsen suggested that Gulf states found themselves in the delicate position of navigating both the evolution of geoeconomic changes and the diffusion of power in the global economy and increased domestic uncertainty from pro-democracy and violent Islamist groups. ${ }^{73}$ Beyond the economic challenges of 2014, little has changed. While GCC states were largely able to circumvent dissent, structural conditions remain that leave regimes vulnerable in the longer term to demands for greater political accountability, while recourse to Islamic 
legitimacy leaves regimes open to criticism from the religious groups who also seek to capitalise on societal differences.

Within the context of such machinations, Bahrain and Oman find themselves struggling to exert influence and agency, caught in the shadow of their far more powerful neighbours. As a consequence, the two have sought creative responses to structural challenges, along with recourse to diplomatic efforts. In Bahrain there have been serious moves towards fracking amid concerns about depleting oil reserves and a brain drain to the Emirates and Saudi Arabia. ${ }^{74}$ In contrast, Oman has sought to use its strategic location as a means of creating influence by upgrading ports in Sohar, Duqm and Salalah, allowing cargo to bypass the Strait of Hormuz.

Omani developments take place amid rising friction with their neighbours and domestic economic concerns stemming from questions of succession. Fundamental to such decisions are desires to maintain independence and reduce vulnerability to political pressure from Saudi Arabia and the UAE, particularly in light of Muscat's relationship with Tehran. Yet Omani developments have broader repercussions for the GCC, with Saudi investments in infrastructure building seen by some as a means of reducing the Emirati monopoly on Gulf trading roots. ${ }^{75}$ Such competition takes place within an increasingly militarised Gulf and proliferation into the Horn of Africa, which adds Chinese and Egyptian aspirations into an already volatile mix.

\section{Moments of indistinction}

According to Wahhabi traditions, when Muslims die they are buried in an unmarked grave to prevent idolatry. Such protocols are observed by rulers and ruled alike. It was no surprise that when King Abdullah of Saudi Arabia was buried on 24 January 2015, it was in such a grave at an austere public cemetery named El Ud. Abdullah's funeral was attended by a number of Middle Eastern leaders, yet Oman's well-respected ruler Sultan Qaboos was not present, prompting questions about his health. Omanis are not alone in fearing for the health of their much-loved ruler, particularly as he is yet to publicly anoint a successor, leading to political and economic uncertainty. ${ }^{76}$ Across the Gulf, questions of succession plague a number of monarchies amid concerns of the repercussions of political reform.

Almost two and a half years after the death of Abdullah, Mohammad bin Salman, the son of King Salman was named as Crown Prince of Saudi Arabia, replacing the former incumbent Mohammad bin Nayef. Known across the region as MbS, the young Crown Prince rapidly progressed through the kingdom's upper echelons, leaving his mark on political life. One apocryphal story recounts how MbS gained the nickname Abu Rasasa - the father of the bullet - after sending a bullet in the post to a man who refused to help him appropriate property. ${ }^{77}$

Although initially installed as Minister of Defence, during which time he launched efforts to restrict Houthi military action, MbS was soon positioned as Crown Prince, heir apparent to the throne. Seemingly reform minded and seeking to facilitate the transition to a 'post-oil' economy, the Crown Prince's moves risk opening the deep 
fissures within the fabric of the Saudi state amid efforts to curb the power of the clerics and prevent the spread of violent Wahhabi thought. ${ }^{78}$

The Crown Prince quickly embarked on an anti-corruption drive across the kingdom, resulting in the arrests of eleven prominent royals and two hundred members of the Saudi business elite, in a move referred to by Madawi Al Rasheed as a 'theatrical performance'. Although framed as an effort to reduce corruption, it was clear that this was also an attempt to secure his position amid the uncertainty and shifting sands of political allegiance and ambitions within the Al Saud. ${ }^{79}$ The anti-corruption drive was largely well received by young Saudis, with strict legislation preventing the proliferation or acknowledgement of extremist ideologies on social media. ${ }^{80}$ Yet faith in the Saudi economy had dwindled as a consequence of the level of corruption. As one official told the New York Times, 'Corruption is at every level, and there are hundreds of billions of riyals that are lost from the national economy every year ... The point here was mainly to shock the system, to send a message that this will not be tolerated anymore and that nobody is immune. 81

MbS was also a vocal supporter of the need to diversify the kingdom's economy, driven by Vision 2030. Central to this vision was a move away from a reliance on oil, along with the development of NEOM, a $\$ 500$ billion megacity, viewed as the new commercial capital of the kingdom, ${ }^{82}$ as part of a privatisation designed to create more jobs for Saudis and to facilitate the transition to the post-oil age. Although comprised of territory in Saudi Arabia, Egypt and Jordan, the new city will be under Saudi jurisdiction. ${ }^{83}$ In support of this - and with the aim of attracting tourists from the kingdom and beyond - greater importance has been given to the kingdom's pre-Islamic history, with a number of heritage sites being protected with United Nations Educational, Scientific and Cultural Organization (UNESCO) status. Tourism was also mooted as a potential source of income, yet the impact of this - and recognition of pre-Islamic sites - upon the kingdom's social contract remains to be seen. ${ }^{84}$

The Crown Prince also announced a move towards a 'more tolerant' form of Islam, threatening to crack down on members of the ulema who opposed his programme of reforms and professed that he wanted to 'destroy' extremist ideologies, evoking memories of Faisal in the process. ${ }^{85}$ It was also supported by the aforementioned anti-terrorism coalition, comprised entirely of Sunni states but seemingly dominated by Pakistani 'boots on the ground', before outright rejection from the Pakistani government.

Beyond the kingdom's borders, the Crown Prince embarked on a more proactive foreign policy that sought to reassert Saudi Arabia's dominance across the Middle East, restricting Iranian influence and continuing the burgeoning rapprochement with Israel. ${ }^{86}$ Foreign policy has been driven by an explicitly anti-Iranian agenda, leading to military escalation in Yemen - a view used to justify the war particularly in the Emirates ${ }^{87}$ - while in Lebanon, a working relationship between Saad Hariri and Hizballah officials resulted in a bizarre series of events in late 2017. Amid Saudi concerns about the Lebanese political climate, Hariri was summoned to Riyadh and forced to resign before being held under house arrest. After his release Hariri returned to Lebanon, where he rescinded his resignation. 
Yet the kingdom continued to rely on key allies to help achieve its aims. The close friendship between Mohammed bin Salman and Mohammed bin Zayed ${ }^{88}$ - the Crown Prince and de facto ruler of the UAE - meant that Saudi military efforts in Yemen were also supported by the UAE, along with Egypt, Bahrain and Qatar, although the latter was expelled from the Saudi-led coalition amid escalating tensions between the two. ${ }^{89}$ Relations with the United States rapidly thawed under Trump and Riyadh was the first official trip made by the new President after coming to office, demonstrating the importance of not only relations with Saudi Arabia but his personal relationship with the Crown Prince. In an unofficial account of time in the Trump White House, it was reported in June 2017 that the President said, 'We've put our man on top', after King Salman removed Mohammed bin Nayef as Crown Prince and replaced him with his son..$^{90}$ In the months that followed, Trump was vocal in his support of Salman and his son, on one occasion tweeting, 'I have great confidence in King Salman and the Crown Prince of Saudi Arabia, they know exactly what they are doing. ${ }^{91}$

The close relationship between Trump and MbS makes criticism of the kingdom in the United States more powerful. MbS' father, King Salman, had previously been identified as 'Fund-Raiser in Chief' of Saudi funding for violent extremism across the world, where an estimated $\$ 90$ billion was given to mosques and clerics in the twenty years before $9 / 11$, many of whom used the money to finance extremist motivated violence. While Saudi Arabia does not tolerate extremist thought within the kingdom, it is widely accepted that it is openly backing, funding and arming radical Islamic jihadists outside the Saudi Kingdom. ${ }^{92}$ Tackling this perception was a key goal of the new leadership in Riyadh, yet the murder of Jamal Khashoggi, a Saudi dissident, provoked a great deal of international condemnation not only concerning the death of Khashoggi but over the kingdom's domestic and foreign policy.

\section{Old questions, new answers?}

On 6 December 2017, US President Donald Trump broke with decades of US policy and stated that it was 'time to officially recognise Jerusalem as the capital of Israel. ${ }^{93}$ The move to recognise Jerusalem as Israel's capital seemingly ended the moribund peace process. If a US administration had acted in such a manner in the past, Arab leaders would have vehemently rejected the move, and the possibility of widespread violence would have been high. Yet in spite of pockets of unrest across the region again stemming from grassroots movements - there was little in the way of a coordinated response. The old question about Palestinian autonomy was populated with new apathy.

Although most states across the Arab world have played with the 'Palestinian football', the cause has long been removed from their strategic priorities. In spite of strong domestic anti-Israeli sentiment, Egyptian leaders tacitly accepted the embassy move. ${ }^{94}$ Although clerics at $\mathrm{Al}$ Azhar were critical, most followed government 
guidelines, choosing to focus their Friday sermons on 'family values' rather than events in Jerusalem. ${ }^{95}$ Unsurprisingly, Saudi Arabia was largely quiet on the matter. On visiting the Washington Institute, MbS offered 'mild rebuke' of the decision and presented an optimistic vision of Saudi-Israeli relations, but only when asked. ${ }^{96}$ Yet the Crown Prince was vociferous in his criticism of the Palestinian leadership. At a meeting with Jewish leaders in the United States, it was reported that MbS said, 'It's about time that the Palestinians accept the offers, and agree to come to the negotiating table - or they should shut up and stop complaining. ${ }^{97}$

Such a response is hardly unexpected given Saudi manoeuvres in recent years. Shortly after publicly rebuking Saad Hariri, Mahmoud Abbas, the leader of the Palestinian Authority (PA) was called to Riyadh to hear a Saudi peace plan. Reports suggested that the Saudi plan was presented to Abbas along with an ultimatum: accept it or resign. ${ }^{98}$ As the outline was comprised of a number of concessions that no Palestinian leader could accept, Abbas was furious. The plan did allow for the establishment of a Palestinian 'entity', but this would include non-contiguous parts of territory in Gaza, parts of the West Bank (Areas A, B and 10\% of C), leaving limited territorial sovereignty. Moreover, the vast majority of Israeli settlements across the West Bank would remain. The most troublesome parts of the plan suggested that there would be no right of return for Palestinian refugees and the capital of this entity would be in Abu Dis or Ramallah, not Jerusalem. ${ }^{99}$

In response to both Trump's decision and the Saudi ultimatum, Abbas was steadfast: 'Now we say "No" to Trump, we won't accept his plan - we say the "deal of the century" is the slap of the century.' ${ }^{\prime 100}$ The PLO Executive Committee was urged to 'suspend recognition of Israel until it recognises the State of Palestine on the 1967 borders' while the PLO stated that the Oslo Agreements 'no longer stand'. ${ }^{101}$ Two days after the Jerusalem announcement, Yoav Galant, the Israeli Construction and Housing Minister, announced plans to build fourteen thousand new 'units' in settlements across the West Bank and East Jerusalem.

Later that year, the Knesset passed a 'nation state law' that was framed by Prime Minister Benjamin Netanyahu as 'a defining moment in the history of the state', ${ }^{102}$ which offers a legal response to existential questions about Israel, codifying 'the basic principle of our existence. The law enshrined the right to exercise national self-determination in Israel as unique to the Jewish people, establishing settlement as a national value and labouring to 'encourage and promote its establishment and development', making spatial ordering and transformation a key part of the Israeli sovereign project. ${ }^{103}$

\section{Coming home to roost}

In recent years, cartoons have appeared in a number of regional newspapers portraying Saudi Arabia as the ideological founder and sponsor of violent Salafist extremism. One cartoon depicts King Salman placing money into a jihadi piggy bank, while another shows the King throwing a boomerang with the face of a jihadi away from the kingdom 
towards Syria. By their very nature boomerangs return to where they were thrown from, suggesting that such problems will return to Saudi Arabia in the future.

State policy in the face of regional and international challenges has only served to support such perceptions. Amid a range of political, economic and ideological challenges, regimes have firmly positioned themselves within broader normative and security environments in the quest for legitimacy and ultimately survival. Driven by sectarianisation, in some cases, this has resulted in alliances that will ensure regime survival in the face of particular threats but that are unpalatable to domestic populations. The collapse of the distinction between regional and domestic is escalating, with potentially dire consequences for people, the ordering of space and territorial borders. As sectarianisation narratives find traction, sectarian conflict risks becoming a selfperpetuating truth, with devastating repercussions, posing serious challenges to those aiming for desectarianisation.

The fragmentation of the region post 2011 has posed a number of existential challenges to regime survival. In an effort to ensure survival, state-building projects have become increasingly exclusionary, defining themselves against an outside, leading to widespread marginalisation, repression and disenfranchisement. Yet amid widespread uncertainty and instability, (politically charged) religion offers a semblance of certainty for both regimes and individuals amid these struggles.

Recourse to religion and tradition to circumvent opposition created a zone of possibility to be shaped by the interaction of various groups. The struggle to exert influence, lay claim to legitimacy or implement democracy led to accusations of state failure or weakness. Some even predicted the collapse of the Gulf regimes, most obviously in Christopher Davidson's After the Sheikhs. ${ }^{104}$ Although Davidson's claims were ultimately premature, his initial premise has some merit. Although traditionally secure states such as Saudi Arabia, Kuwait, Qatar and the UAE have largely escaped from the problems of the Arab Uprisings, this position is not tenable in the medium to long term, feeding into the crisis of legitimacy and instability that drives sectarianisation processes.

In such conditions, the struggle to shape political life becomes increasingly important, while groups and individuals face precarious futures. In an article in the Financial Times, the former Jordanian Finance Minister Marwan Muasher suggested that the problems facing the Arab world were increasing, with societal fissures deepening and economic challenges escalating. For Muasher, fractures in society are 'the biggest problem, and unfortunately very few leaders are paying attention to it'. One potential outcome is 'another Arab Spring ... the status quo is not sustainable. ${ }^{105}$ One additional consequence, for Shadi Hamid, is that amid such conditions and increasing repression, Islamist groups move towards violent escalation as they are pushed to the periphery of political projects. ${ }^{106}$

The complexity of contemporary political life underpinned by often competing geopolitical agendas means that regimes across the Middle East operate with a profound sense of insecurity. Such conditions are hardly new, yet the perceived severity of the threats facing the region's rulers have multiplied, challenging stability from a range of different vantage points. As scholars of International Relations are aware, existential fear breeds a security dilemma, which, without careful management, increases 
instability. Regimes across the Middle East now face a number of often competing security dilemmas, including the traditional dilemma between states but also occurring within states. A number of these internal security dilemmas have regional repercussions, particularly when embedded within shared normative environments. ${ }^{107}$ In such precarious conditions, maintaining security or reassuring those whose security is to be guaranteed is increasingly difficult. As fear permeates the region, along with sectarianisation processes, it facilitates the descent into violent conflict and makes the possibility of de-escalation increasingly unlikely.

\section{Conclusions}

In one of the more powerful analyses of the Arab Uprisings, Hamid Dabashi argues that the post-uprisings landscape has been defined by the struggle between domestic tyranny and globalised disempowerment. ${ }^{108}$ In this moment, a new geography emerges as states seek to reimagine the 'moral map' of the Middle East away from the colonial legacy of 'the West', essentially 'altering the very geography of how we think and fathom the world. ${ }^{109}$ Moreover, the spread of identities and ideologies across state borders resulted in the collapse of the distinction between internal and external. This conflation of national and regional dynamics obfuscates the counter-revolutionary factions at play, while also establishing a new cosmopolitan geography.

Within this new geography, spatial borders have been eroded as a new means of ordering life, while schisms within and across states have deepened. Debate about the resolution of domestic unrest involved discussions of a move towards federalism, underpinned by power-sharing agreements such as those seen in Lebanon. An increasingly popular view suggested that an ethno-sectarian redistribution across the region would bring stability to the region. ${ }^{110}$ Indeed, for many, the centrifugal forces shaping the region were interpreted as the rearrangement of populations in an attempt to "better fit the nation states.111 After the uprisings, these centrifugal forces challenged the spatial organisation of politics through the emergence of a new system of ordering life, increasingly along sectarianised lines, eroding the sovereign power of the state in the process.

The geography of ideas and ideologies also transcend the construction of national borders. Ideas of liberation and empowerment served as a source of possibility and inspiration, providing a compelling means through which to reject 'being thus'. As Dabashi argued, the uprisings also served as a means of creating a new geography of hope, challenging the colonial legacy of external actors and the counter-revolutionary forces that had regulated spatial dynamics across the Middle East. In spite of this optimism, following the initial successes of the revolutionary groups, a more restrictive and counter-revolutionary set of forces began to shape the region.

Political life is shaped in accordance with the context and contingency of space yet underpinning a great deal of recent events is the increasingly toxic rivalry between Saudi Arabia and Iran that capitalises on - and drives - the fragmentation of political projects. Although a number of organisations have sought to embark on track II diplomatic processes, there appears little scope for rapprochement at present given the conflation of political issues with geopolitical concerns and efforts to cultivate 
Islamic legitimacy. As a consequence, while the two states have sought to capitalise on opportunities that present themselves, this feeds into the fragmentation of political organisation and supports sectarianisation processes.

Where authority and legitimacy have been seriously challenged, the move to more community grounded identities that often share some form of identity or ideology with external actors has supported such claims. Such counter-revolutionary forces were supported by external actors, whose own interests did not align with those who took to the streets across the region to express political goals. Although his optimism appears misguided, we should not ignore Dabashi's words, which urge us to look beyond the clash of imperialism, Orientalism and lazy journalism. Doing so results in the construction of 'truth' posited upon 'the grid of prosaic normativity, a reading of reality by way of sustaining the power and the benefits of imperial domination. ${ }^{112}$

Yet as counter-revolutionary forces prevail, the dreams and hopes of those who took to the streets have been crushed by the bureaucratic systems of biopolitical machinery designed to regulate life and, where necessary, to subjugate it to death. Ultimately, amid widespread devastation and humanitarian crises, the people of the region have paid the heaviest price.

\section{Notes}

1 See Michael Axeworth and Patrick Milton, 'A Westphalian Peace for the Middle East' (Foreign Affairs, 10.10.16), available at www.foreignaffairs.com/articles/europe/201610-10/westphalian-peace-middle-east (accessed 11.10.16); Richard N. Haas, 'The New Thirty Years' War' (Project Syndicate, 21.07.14), available at www.project-syndicate. $\mathrm{org} /$ commentary/richard-n--haass-argues-that-the-middle-east-is-less-a-problem-tobe-solved-than-a-condition-to-be-managed?barrier=accessreg (accessed 11.10.16); Greg R. Lawson, 'A Thirty Years' War in the Middle East' (National Interest, 16.04.14), available at http://nationalinterest.org/feature/thirty-years-war-the-middle-east-10266 (accessed 11.10.16); Brendan Simms, Michael Axworth and Patrick Milton, 'Ending the New Thirty Years War' (New Statesman, 26.01.16), available at www.newstatesman. com/politics/uk/2016/01/ending-new-thirty-years-war (accessed 11.10.16); David Rothkopf, 'A Time of Unprecedented Instability?' (Foreign Policy, 21.07.14), available at http://foreignpolicy.com/2014/07/21/a-time-of-unprecedented-instability (accessed 21.07.14); Bernard Lewis, 'Rethinking the Middle East' (Foreign Affairs, 1992), available at www.foreignaffairs.com/articles/middle-east/1992-09-01/rethinkingmiddle-east (accessed 21.07.14).

2 Testimony, Richard Haas.

3 Lorenzo Kamel, 'Reshuffling the Middle East: A Historical and Political Perspective', International Spectator 51:3 (2016), 132-41.

4 Joshua Landis, 'The Great Sorting Out: ethnicity and the Future of the Levant' (Qifa Nabki, 18.12.13), available at https://qifanabki.com/2013/12/18/landis-ethnicity (accessed 18.12.13); Robert Bowker, Ending Sykes-Picot: The Arab World and the West After 2011 (HH Sheikh Nasser al-Mohammad al-Sabah Publication Series 2013), available at www.dur.ac.uk/resources/alsabah/al-SabahPaperBowkerSeptember2013. pdf (10.08.19). 
5 See interviews with Iraqi film-maker, Syrian academic, Syrian analysts, Yemen analysts, Iraqi analyst, Lebanese journalists, Bahraini MPs, Bahraini cleric, 2014-2018.

6 Interview with Yemen analyst, 2018.

7 Phillips, Battle for Syria.

8 Interview with Bahraini academic, 2018.

9 Fred Halliday, 'A New Global Configuration', in Ken Booth and Timothy Dunne (eds), Worlds in Collision - Terror and the Future of Global Order (New York: Palgrave Macmillan), p. 235.

10 See Richard N. Haass, 'The New Middle East', Foreign Affairs, 85 (2006), 2-12; Alexander T. J. Lennon (ed.), The Epicenter of Crisis. The New Middle East (Cambridge, MA: MIT Press, 2008); Robert Malley and Peter Harling, 'Beyond Moderates and Militants', Foreign Affairs, 89 (2010), 18-29; Vali Nasr, The Shia Revival: How Conflicts Within Islam Will Shape the Future (New York: Norton, 2007); Ottaway et al., The New Middle East; Nicolas Pelham, A New Muslim Order: The Shia and the Middle East Sectarian Crisis (London: I. B. Tauris, 2008); Philip Seib, New Media and the New Middle East (New York: Palgrave Macmillan, 2009).

11 Morten Valbjørn and André Bank, 'The New Arab Cold War: Rediscovering the Arab Dimension of Middle East Regional Politics', Review of International Studies, 38 (2012), 3-24.

12 Jerrold Green, 'Are Arab Politics Still Arab?', World Politics, 38 (1986), 611-25.

13 Paul Noble, 'The Arab System: Pressures, Constraints, and Opportunities', in Bahgat Korany and Ali E. Hillal Dessouki (eds), The Foreign Policies of Arab States (Boulder, CO: Westview, 1991), p. 57.

14 Hashim, S. Al-Intifadhat al-'Arabiya 'ala Dhaou Falsafit at-Tarikh [The Arab Uprising in Light of the Philosophy of History] (Beirut: Dar al-Saqi, 2013).

15 Shibley Telhami, Anwar Sadat Chair for Peace and Development University of Maryland/Zogby International 2006 Annual Arab Public Opinion Survey (8 February 2007).

16 Bassel F. Salloukh, Overlapping Contests and Middle East International Relations: The Return of the Weak Arab State (Project on Middle East Political Science, 2015), available at https://pomeps.org/2015/08/12/overlapping-contests-and-middle-eastinternational-relations-the-return-of-the-weak-arab-state (accessed 13.08.15).

17 Interview with Saudi political theorist, 2018.

18 Interview with Syrian analyst, 2017.

19 Interview with Bahraini Shi'a cleric, 2018.

20 In $201143 \%$ either agreed or strongly agreed with the statement 'it would be better for my home country if religion were separated from politics' and in 2015 this number had risen to 52\%. See Arab Opinion Index 2015, p. 23.

21 This was a prominent theme across a number of interviews.

22 Archar, The People Want.

23 Interview with Lebanese journalist, 2017.

24 Baumann, 'Social Protest'. The term mafia was routinely used by interviewees to describe life in Lebanon, Syria and Iraq.

25 Interview with Syrian author, 2018.

26 Simon Mabon 'The Battle For Bahrain: Iranian-Saudi Rivalry', Middle East Policy, 19:2 (2012), 84-97.

27 Interview with ex-Bahraini MP.

28 See WikiLeaks, 'The Street is Stronger Than Parliament'. 
29 Mabon and Royle, Origins of ISIS. See also Mabon 'Nationalist Jahiliyya'.

30 Alex MacDonald, 'Controversial Iraqi Militias Now Part of Army after Parliament Vote' (Middle East Eye, 26.11.16), available at www.middleeasteye.net/news/iraqsparliament-legalizes-controversial-pmus-566417926 (accessed 26.11.16).

31 Ali Khamenei, Supreme Leader of Iran called for 'divine vengeance.' 'Iran Furious Over Saudi Arabia's Execution of Shi' ite Sheikh Nimr Al-Nimr' (Memri, 01.04.16), available at www.memri.org/reports/iran-furious-over-saudi-arabias-execution-shiite-sheikhnimr-al-nimr (accessed 04.01.16).

32 'Iran says Ambassador to Remain in Kuwait Despite Row' (Reuters, 24.07.17), available at www.reuters.com/article/us-iran-kuwait-diplomacy/iran-says-ambassador-toremain-in-kuwait-despite-row-idUSKBN1A91CC?il=0 (accessed 24.07.17).

33 Testimony, Hamli.

34 Hashemi and Postel, Sectarianization. Although most visible in conflicts in Iraq, Syria and Yemen, it is also a feature of Lebanon, Bahrain, Saudi Arabia, Kuwait and Iran.

35 Testimony, Hamli.

36 Interview with Turkish activist, 2017.

37 Christopher Phillips and Morten Valbjørn, " "What Is in a Name?”: The Role of (Different) Identities in the Multiple Proxy Wars in Syria, Small Wars \& Insurgencies, 29:3 (2018), 414-33.

38 Testimony, Haider Al Khoei.

39 Testimony, Haid Haid.

40 Matthiesen, Sectarian Gulf, p. 127.

41 Testimony, Danahar.

42 This was a point made by several interviewees from Lebanon. Similar issues also appear in Syria and Iraq.

43 Testimony, Haider Al Khoei.

44 Testimony, Haid Haid.

45 Testimony, Haider Al Khoei.

46 Interview with Kurdish policy advisor. See also 'Iraq's Muqtada al-Sadr Makes Rare Saudi Visit' (Al Jazeera, 21.07.17), available at www.aljazeera.com/news/2017/07/iraqmuqtada-al-sadr-rare-saudi-visit-170731073908238.html (accessed 21.07.17).

47 Phillips, Battle for Syria.

48 Interview with Lebanese journalist, 2017.

49 Ibid.

50 Phillips, Battle for Syria.

51 Testimony, Trenin.

52 Mabon, 'Muting the Trumpets'.

53 Jeffrey Goldberg, 'The Obama Doctrine' (Atlantic, April 2016), available at www. theatlantic.com/magazine/archive/2016/04/the-obama-doctrine/471525/\#5 (accessed 26.11.16).

54 Turki Al Faisal, 'Mr. Obama, We Are Not "Free Riders"' (Arab News, 14.03.16) www. arabnews.com/columns/news/894826 (accessed 15.03.16).

55 Adel Bin Ahmed Al Jubeir, 'Can Iran Change?' (New York Times, 19.01.16), available at www.nytimes.com/2016/01/19/opinion/saudi-arabia-can-iran-change.html?_r=2 (accessed 20.01.16).

56 Ibid.

57 Mabon, 'Muting the Trumpets'.

58 The 2016 Arab Opinion Index found that $86 \%$ of respondents 'disapproved of their countries' recognition of Israel' while $80 \%$ stated that Israel 'certainly' posed a threat to 
the Arab region. See http://arabcenterdc.org/wp-content/uploads/2017/04/2016-ArabOpinion-Index-Executive-Summary-for-web.pdf (accessed 26.11.16).

59 See Adham Saouli, Middle Powers (London: Hurst, 2018); Clive A. Jones and Guzansky, Yoel, 'Israel's Relations with the Gulf states: Toward the Emergence of a Tacit Security Regime?' Contemporary Security Policy, 38:3 (2017), 398-419.

60 'King Hamad Supports Gulf Security Dialogue' (WikiLeaks, 01.11.06), available at https://wikileaks.org/plusd/cables/06MANAMA1849_a.html (accessed 26.11.16).

61 See Merom, Gil. 'Israeli Perceptions of the Iranian Nuclear Threat', Political Science Quarterly, 132:1 (2017), 87-118; Ehud Eiran and Martin B. Malin, 'The Sum of all Fears: Israel's Perception of a Nuclear-Armed Iran', Washington Quarterly, 36:3 (2013), 77-89; Scott Peterson, 'Imminent Iran Nuclear Threat? A Timeline of Warnings Since 1979', Christian Science Monitor, 8 (2001), available at www. csmonitor.com/World/Middle-East/2011/1108/Imminent-Iran-nuclear-threat-Atimeline-of-warnings-since-1979/Earliest-warnings-1979-84 (accessed 02.08.19); 'Netanyahu's Claim that Iran is "Six Months" from Having Nuclear Bomb Material' (Washington Post, 16.09.12).

62 Amir Lupovici, 'Securitization Climax: Putting the Iranian Nuclear Project at the Top of the Israeli Public Agenda (2009-2012)', Foreign Policy Analysis, 12:3 (2016), 413-32; Hossein Pour-Ahmadi and Sajad Mohseni, 'The Obama and Securitization of Iran's Nuclear Energy Program', Iranian Review of Foreign Affairs, 3:2 (Summer 2012), 143-74; Jarrod Hayes, 'Identity and Securitization in the Democratic Peace: The United States and the Divergence of Response to India and Iran's Nuclear Programs', International Studies Quarterly, 53 (2009), 977-99.

63 Patrick Wintour, 'Gulf Plunged into Diplomatic Crisis as Countries Cut Ties with Qatar' (Guardian, 05.06.17), available at www.theguardian.com/world/2017/jun/05/ saudi-arabia-and-bahrain-break-diplomatic-ties-with-qatar-over-terrorism (accessed 05.06.17).

64 'Qatari Emir: Our Sovereignty Is a Red Line' (Al Jazeera, 30.10.17), available at www. aljazeera.com/news/2017/10/qatar-emir-blockading-countries-regime-change171029194842654.html (accessed 30.10.17).

65 Interview with Shia Bahraini cleric 2018.

66 Courtney Freer, 'Same But Different: The GCC Continues to Clash Over Islamists' (Middle East Centre, 06.06.17), available at http://blogs.lse.ac.uk/mec/2017/06/ 06/same-same-but-different-the-gcc-continues-to-clash-over-islamists (accessed 26.11.16).

67 Interviews with Bahraini academic 2018.

68 Patrick Wintour, 'Land of Milk and Money: Qatar Looks to Farms to Beat the Gulf Boycott' (Guardian, 20.10.17), available at www.theguardian.com/world/2017/oct/20/ land-of-milk-and-money-qatar-looks-to-farms-to-beat-the-gulf-boycott (accessed 21.10.17).

69 'Qatar Launches “Blockade-Busting” Port, One of Region's Largest' (New Arab, 05.09.17), available at www.alaraby.co.uk/english/news/2017/9/5/qatar-launchesblockade-busting-port-one-of-regions-largest (accessed 05.09.17).

70 Yamada, 'Gulf-Asia Relations as "Post-Rentier” Diversification? The Case of the Petrochemical Indus- try in Saudi Arabia', Journal of Arabian Studies, 1 (2011), 101-3.

71 Ben Simpfendorfer, The New Silk Road: How a Rising Arab World is Turning Away From the West and Rediscovering China (Basingstoke, UK: Palgrave Macmillan, 2009), pp. 30-2. 
72 Kristian Coates Ulrichsen, 'Links Between Domestic and Regional Security', in Kristian Coates Ulrichsen, The Changing Security Dynamics of the Persian Gulf (London: Hurst, 2014), pp. 23-41.

73 Kristian Coates Ulrichsen, 'Repositioning the GCC States in the Changing Global Order', Journal of Arabian Studies, 1:2 (2011), 231-47.

74 Interview with Bahraini oil executive 2014.

75 Camille Lons, 'Battle of the Ports: Emirates Sea Power Spreads from Persian Gulf to Africa' (Newsweek, 08.03.18), available at www.newsweek.com/battle-ports-emiratessea-power-spreads-persian-gulf-africa-1051959 (accessed 08.03.18).

76 A position that is quickly apparent in conversations with those Omanis willing to talk about succession.

77 Dexter Filkins, 'A Saudi Prince's Quest to Remake the Middle East' (New Yorker, 09.04.18), available at www.newyorker.com/magazine/2018/04/09/a-saudi-princesquest-to-remake-the-middle-east (accessed 09.04.18).

78 Mabon, 'Family Affair'; Al Rasheed, Salman's Legacy.

79 Al Rasheed, Salman's Legacy.

80 Interviews with Saudi academic 2017.

81 Thomas Freedman, 'The Upstart Saudi Prince Who's Throwing Caution to the Winds' (New York Times, 14.11.17), available at www.nytimes.com/2017/11/14/world/ middleeast/saudi-arabia-mohammed-bin-salman.html?action=click\&contentCollect ion $=$ Middle $\% 20$ East\&module $=$ RelatedCoverage\&region=Marginalia\&pgtype $=$ article (accessed 15.11.17).

82 Vivian Nereim and Alaa Shahine, 'Saudi Arabia Crown Prince Details Plans for New City: Transcript' (Bloomberg, 26.10.17), available at www.bloomberg.com/news/ articles/2017-10-26/saudi-arabia-crown-prince-details-plans-for-new-city-transcript (accessed 26.11.16).

83 Ibid.

84 Interview with Saudi analyst who advises Saudi embassy 2017 and with Saudi academic. See also Mabon, 'Family Affair'.

85 Sam Meredith, 'Saudi Arabia Promises a Return to "Moderate Islam"' (CNBC, 25.10.17), available at www.cnbc.com/2017/10/25/saudi-arabia-promises-a-return-tomoderate-islam.html (accessed 26.10.17).

86 Jones and Guzansky, 'Israel's Relations with the Gulf States'. Following the international condemnation of the murder of the Saudi dissident Jamal Khashoggi, Israeli Prime Minister Benjamin Netanyahu suggested that the Kingdom should 'get a pass' because the larger problem is 'Iran, and we have to make sure that Iran does not continue the malign activities that it has been engaged in'. See Yaron Steinbuch, 'Netanyahu: Saudi Arabia Deserves a Pass for Khashoggi Murder' (New York Post, 02.11.18), available at https://nypost.com/2018/11/02/netanyahu-saudi-arabia-deserves-a-pass-forkhashoggi-murder (accessed 03.11.18).

87 One interviewee told me that 'we went to war in Yemen because we are next', referring to fears about Iranian expansionism that began to pervade Emirati society, including the mother of one Emirati soldier killed in Yemen speaking on TV and saying that 'we have to stop them there', referring to Iran. Moreover, it was also suggested that ideas of Arab nationalism were only now evoked in reference to Iran.

88 Declan Walsh, 'Tiny, Wealthy Qatar Goes Its Own Way, and Pays for It' (New York Times, 22.01.18), available at www.nytimes.com/2018/01/22/world/middleeast/qatarsaudi-emir-boycott.html (accessed 23.01.18). 
89 Many in Oman have been critical of the 'Yemen adventure', including Sultan Qaboos, who are concerned about the destabilising impact of the conflict upon the region. Giorgio Cafiero and Theodore Karasik, 'Yemen War and Qatar Crisis Challenge Oman's Neutrality' (Middle East Institute, 06.07.17), available at www.mei.edu/ content/article/oman-s-high-stakes-yemen (accessed 06.07.17).

90 “"We Put Our Man on Top", Trump said on MBS, Book Claims' (Al Jazeera, 05.01.18), available at www.aljazeera.com/news/2018/01/put-man-top-trump-mbs-book-claims180105124054629.html (accessed 05.01.18).

91 Tweet (Twitter, 06.11.17, $11.03 \mathrm{pm}$ ), available at https://twitter.com/realDonaldTrump/ status/927672843504177152 (accessed 26.11.16).

92 Testimony, Haider Al Khoei.

93 The White House, 'Statement by President Trump on Jerusalem'.

94 David D. Kirkpatrick, 'Tapes Reveal Egyptian Leaders' Tacit Acceptance of Jerusalem Move' (New York Times, 06.01.2018), available at www.nytimes.com/2018/01/06/ world/middleeast/egypt-jerusalem-talk-shows.html (accessed 08.01.18); 'Egypt Denies Report That It Accepts Trump's Jerusalem Recognition' (Times of Israel, 07.01.2018), available at www.timesofisrael.com/egypt-denies-report-that-it-accepts-trumpsjerusalem-recognition (accessed 08.01.18).

95 Shahira Amin, 'Sisi Performs Balancing Act in Wake of Trump's Jerusalem Move' (AlMonitor, 12.12.2017), available at www.al-monitor.com/pulse/originals/2017/12/egyptsisi-balance-trump-decision-jerusalem-israel-azhar.html (accessed 16.12.12).

96 Robert Satloff, 'Mohammed bin Salman Doesn't Want to Talk About Jerusalem' (Foreign Policy, 14.12.2017), available at http://foreignpolicy.com/2017/12/14/ mohammad-bin-salman-doesnt-want-to-talk-about-jerusalem (accessed 16.12.12).

97 TOI Staff, 'Palestinians Must Make Peace or Shut Up, Saudi Crown Prince Said to Tell US Jews' (Times of Israel, 29.04.18), available at www.timesofisrael.com/palestiniansmust-make-peace-or-shut-up-saudi-crown-prince-said-to-tell-us-jews (accessed 30.04.18).

98 Sue Surkes, 'Saudis Told Abbas to Accept Trump Peace Plan or Resign - Report' (Times of Israel, 12.11.17), available at www.timesofisrael.com/saudis-told-abbas-toaccept-trump-peace-plan-or-resign-report (accessed 12.11.17); Adnan Abu Amer, 'Details of Abbas' Mysterious Saudi Trip Still Scarce' (Al-Monitor, 16.11.17), available at www.al-monitor.com/pulse/originals/2017/11/palestine-saudi-arabia-abbasresignation-pressure-peace-us.html (accessed 17.11.17).

99 Anne Barnard, David M. Halbfinger and Peter Baker, 'Talk of a Peace Plan That Snubs Palestinians Roils Middle East' (New York Times, 03.12.17), available at www.nytimes.com/2017/12/03/world/middleeast/palestinian-saudi-peace-plan. html (accessed 04.12.17); Samia Nakhoul, Stephen Kalin and Suleiman Al Khalidi, 'Despite Furor Over Jerusalem Move, Saudis Seen on Board with U.S. Peace Efforts' (Reuters, 8.12.17), https://news.yahoo.com/despite-furor-over-jerusalemmove-saudis-seen-board-183218008.html?guce_referrer=aHR0cHM6Ly93d3cu ZWNvc2lhLm9yZy9zZWFyY2g_cT1OYWtob3VsJTJDK0thbGluK2FuZCthbC 1LaGFsaWRpJTJDKyVFMiU4MCU5OERlc3BpdGUrRnVyb3JlK092ZXIrSmVy dXNhbGVtK01vdmUlRTIIODAlOTkmYWRkb249c2FmYXJp\&guce_referrer_ sig=AQAAAM24PuZt60THRktfl1MTfOG6Ge3KrFiP4bTw_AEGFbMipcMebvW_ GDo4dn1Yu5DPD_v46Xg-PSxUSvB4QJFjGpCAM9A-rsghg PtV0eKUZ9IYLsdKNgmUXpIt8qbmI5F8iMWxkBrbqaofdjObKSHPy DCOXAgBssF9yY3hbWdtQMaa\&guccounter=2 (accessed 10.08.19). 
100 'Mahmoud Abbas Slams Trump Over "Slap of the Century"' (Al Jazeera, 14.01.18), available at www.aljazeera.com/news/2018/01/mahmoud-abbas-slams-trump-slapcentury-180114195614715.html (accessed 14.01.18).

101 'Palestinian Leaders Reconsider Recognition of Israel' (Al Jazeera, 15.01.18), available at www.aljazeera.com/news/2018/01/palestinian-leadership-revokes-recognitionisrael-180116060200939.html (accessed 15.01.18).

102 'Read the Full Jewish Nation-State Law' (Jerusalem Post, 19.07.18), available at www. jpost.com/Israel-News/Read-the-full-Jewish-Nation-State-Law-562923 (accessed 19.07.18).

103 Ibid.

104 Davidson, After the Sheikhs.

105 Andrew England and Heba Saleh, 'How the Middle East Is Sowing Seeds of a Second Arab spring' (Financial Times, 05.03.18), available at www.ft.com/content/a62298441ad3-11e8-aaca-4574d7dabfb6 (accessed 05.03.18).

106 Hamid, Islamic Exceptionalism.

107 Mabon, Saudi Arabia and Iran.

108 Dabashi, The Arab Spring, p. 3.

109 Ibid., p. 6.

110 R. Wright, 'Imagining a Remapped Middle East' (New York Times, 28.09.13), available at www.nytimes.com/2013/09/29/opinion/sunday/imagining-a-remappedmiddle-east. html?pagewanted=all\&_r=0 (accessed 28.09.13); J. Stavridis, 'It's Time to Seriously Consider the Partition of Syria' (Foreign Policy, 09.03.16), available at http:// foreignpolicy.com/2016/03/09/its-time-to-seriously-consider-partitioningsyria (accessed 09.03.16); D. Pipes, 'Like-to-Like Ethnic Migration in the Middle East' (Washington Times, 25.02.15), available at www.washingtontimes.com/news/ 2015/feb/25/daniel-pipes-like-to-like-ethnic-migration- in-the- (accessed 09.03.16); Landis, 'The Great Sorting Out'.

111 Landis, 'The Great Sorting Out'.

112 Dabashi, The Arab Spring, p. 224. 